21. Chernomorec, Ju. Neobhodimost' ukrainskoj radikal'noj ortodoksii [The need for Ukrainian radical orthodoxy]. Retrieved from http://risu.org.ua/ru/index/expert_thought/ open_theme/44887 [in Russian].

22. Chornomorec', Ju. Kritika neopatristiki otcja Georgija Florovs'kogo u radikal'nij teologiï Pandelisa Kalaidzidisa: propushhenij shans zrozumiti poperednikiv. Retrieved from http://theology.in.ua/ua/bp/theologia/contemporary/45303 [in Russian].

23. Mamardashvili, M. K. (1991). Problema cheloveka v filosofii. O chelovecheskom $v$ cheloveke [The problem of man in philosophy. About the human in man]. Moscow: Politizdat [in Russian].

\title{
воЗНЯк Степан,
}

к. філос. н., доцент кафедри філософії, соціології та релігієзнавства

ДВНЗ "Прикарпатський національний університет імені Василя Стефаника"

вул. Шевченка, 57, м. Івано-Франківськ, 76018, Україна

E-mail: stepanwozniak@gmail.com

ORCID: https://orcid.org/0000-0003-2268-5736

\section{ОНТОЛОГІЧНІ НАЧАЛА АНТИЧНОЇ

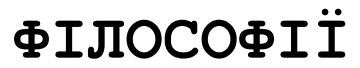

Проаналізовано проблему виявлення смислових контурів античної філософії з точки зору представленості їх у сучасних методологічних та історико-філософських стратегіях. Доведено, щзо відмова від проблематизаиії питання про онтологічні начала античної філософії призводить до локалізації та інструменталізаиї історико-філософського дискурсу. Зосередження уваги на питанні про начала античної філософії демонструється як фундаментальна передумова формування адекватної трансцендентальної дистанції, через яку мислення у своїх сутнісних вимірах та буттєвих характеристиках постає конкретним предметом філософського аналізу.

Ключові слова: антична філософія, метанаратив, онтологічні начала мислення, формалізація, інструменталізація.

(C) Возняк С., 2019

ISSN 1727-9313. ВІСНИК КНТЕУ. 2019. № 1 
Возняк С. Онтологические начала античной философии. Проанализирована проблема выявления смысловых контуров античной философии с точки зрения представленности их в современных методологических и историко-философских стратегиях. Доказано, что отказ от проблематизации вопроса об онтологических началах античной философии приводит к локализации и инструментализации историкофилософского дискурса. Сосредоточение внимания на вопросе о началах античной философии демонстрируется в качестве фундаментальной предпосылки формирования адекватной трансцендентальной дистанции, с которой мышление в своих сущзностных измерениях и бытийных характеристиках предстает как конкретный предмет философского анализа.

Ключевые слова: античная философия, метанарратив, онтологические начала мышления, формализация, инструментализация.

Постановка проблеми. Антична філософія - початок філософії взагалі, як у історичному, так і змістовно-тематичному смислі. Сучасна філософія щодо цього твердження перебуває у парадоксально-суперечливому відношенні: з одного боку, фактичний вплив античної філософії не заперечується; більше того - можна засвідчити певне зростання зацікавленості античною філософською спадщиною як у академічних, так і аматорських колах. Проте, 3 іншого боку, тяжіння сучасної філософії у бік зведення до дискретного набору імперативно орієнтованих на практичну корисність, "злободенну" актуальність та уніфіковану формалізованість інтелектуальних практик-"технологій" апріорно редукує зацікавлення античною філософією до абстрактного твердження про іiї загальну значущість.

У сучасних методологічних практиках прочитання античної філософії відчувається принципова недостатність контекстуального та змістовного занурення у сутнісні виміри філософського мислення, представленого античною традицією. Ця недостатність полягає у такому: попри численні та доволі результативні звернення до античних текстів як фундаменту сучасних логічних, етичних та епістемологічних досліджень, питання про онтологічні та смислові початки античної філософії зводиться до констатації низки сприятливих та/або необхідних передумов і причин різного порядку. Це пов’язано із специфікою сучасної історико-філософської методології, в якій спостерігається принципова, місцями навіть декларативна відмова від спроб схоплення історії філософії як єдиного, стратегічно спрямованого та внутрішньо послідовного метанаративу; таке схоплення нібито тяжіє до тоталітарного способу мислення, в якому локальні, самоцінні та самодостатні філософські ландшафти редукуються та нівелюються. Проте разом із відмовою від "тоталітарного тиску" та "суб’єктивної вседозволеності" наскрізної інтерпретації історії філософії, що найчастіше закидаються Гегелю, Марксу та Гайдеггеру, ми відмовляємось і від здатності осмислити античність у іiі онтологічних, фундаментальних началах. У такому випадку наші звертання до історико-філософських ландшафтів прире- 
чені на роботу виключно із локальними текстами, ідеями та проблемами без можливості встановлення смислового зв'язку між історичною формою мислення й онтологічними початками мислення взагалі. У контексті теми дослідження це формулюється так: відчуження початків філософії - це відчуження філософії загалом.

Аналіз останніх досліджень та публікацій. Попри хронологічну, а місцями і нібито смислову "несучасність", необхідно згадати фундаментальні праці Г. Гегеля, М. Гайдеггера [1] та О. Лосєва [2] як такі, що найбільш системно та комплексно охоплюють та проблематизують античну філософію, виявляючи ії смислову співвіднесеність із подальшим історико-філософським процесом.

У рамках звертання до античної традиції як історико-філософської формації у сучасній європейській та американській філософії слід назвати праці П. Адо [3], Дж. Реале, Д. Антісері, Ф. Коплстона (традиція, що умовно позначена як "континентальна"), Дж. Аннас [4; 5], М. Бюрнеят [6; 7], М. Фреде [8], М. Канто-Спербер, Дж. Барнса, Л. Брісона, Ж. Брюнсвіга, Г. Властоса [9] та багатьох інших (англійська та американська філософія, аналітична філософія). Показово, що якщо європейські тексти тяжіють до комплексного окреслення античної філософії як елемента історії філософії, то традиція англійської та американської філософії здебільшого концентрується на локальних парадигмах та напрямах античності. Найчастіше це філософія Аристотеля, стоїцизм та скептицизм. Також необхідно відмітити праці В. Бібіхіна [10], Н. Мотрошилової, П. Гайденко, Д. Дорофєєва, Р. Свєтлова, І. Мочалової, Ю. Давидова. На окрему увагу заслуговує авторський колектив М. Вольф, П. Бутакова, І. Бєрєстова [11], оскільки опублікована ними в українському журналі "Sententiae" стаття, присвячена проекту аналітичної історії античної філософії, становить прямий інтерес для нашого дослідження.

Вітчизняні дослідження античної філософії характеризуються локальністю у звертанні до окремих ідей та представників (знову-таки, найчастіше зустрічається аналітика аристотелізму та еліністичної філософіï) та пропедевтичністю у питанні створення системної традиції вивчення античної філософії (здебільшого увага концентрується навколо проблеми перекладу текстів та термінів античної філософії). Необхідно відмітити таких авторів: А. Ахутін [12; 13], А. Баумейстер [14], В. Петрушенко [15], О. Паніч [16], М. Попович [17].

Мета дослідження - проаналізувати методологічні можливості входження у питання про начала античної філософії як фундаментальної передумови формування адекватної трансцендентальної дистанції, через яку мислення у своїх сутнісних вимірах та буттєвих характеристиках постає як конкретний предмет філософського аналізу.

Матеріали та методи. У статті використано публікації вітчизняних та іноземних авторів стосовно зазначених проблем, матеріали 
ряду круглих столів, що присвячені проблемі взаємозв'язку античної філософії із сучасністю. В рамках дослідження застосовано загальні методи історико-філософського, теоретичного та текстологічного аналізу.

Результати дослідження. Почнемо 3 більш чіткого окреслення сформульованого нами питання про начала античної філософії. У цьому випадку йдеться не про констатацію причин і передумов зародження останньої. Начала - це і хронологічний початок, і одночасно первинний онтологічний фундамент, 3 якого розпочинається власне філософське мислення. Доскональне знання географічних, кліматичних, культурних, суспільних, формаційних, світоглядних передумов, що сприяли виникненню античної філософії, не описує того, який зсув відбувається у баченні та способі осмислення світу при цьому "нульовому моменті", до якого філософського мислення ще немає, а після якого - ось, воно вже є. Тут радше важливо правильно сформулювати первинне запитання. 3 якого бачення світу і себе в ньому виникає відчуття необхідності розглядати речі не емпірично, не через призму міфологічного тлумачення, але - шукати у речах їх внутрішній, непростежуваний на рівні емпіричного вказування ("ось це") взаємозв'язок, зводити це дорефлексивне, інтуїтивне відчуття пов'язаності не до міфологічних або релігійних одкровень, але - до деякого інтелектуально споглядаємого першоджерела, що постає єдністю відносно множини речей світу? Це питання - не питання мотивації чи історичної результуючої, це питання про спосіб виявлення і знаходження людиною себе у світі та світу саме як внутрішньо єдиного "світу".

Загальна теза про космоцентричний та матеріалістичний світогляд як одне 3 найбільш потужних джерел становлення філософії ("антична культура - це не лише об'єктивізм, це ще й матеріально чуттєвий космологізм). У цьому іiї відмінність від середньовічної філософії та релігії абсолютного духу" [2, с.154-155] є змістовною і продуктивною для розуміння специфіки античного мислення, проте все одно залишає нас у дескриптивно-констатуючому відношенні, оскільки "погляд на світ як космос", що незримо присутній у події античної культури - це недосяжна для сучасних дослідницьких практик у своїй буттєвості й актуальності оптика і кут зору.

Чому недосяжна? Тому що сучасність віддалена від події античної філософії, віддалена і хронологічно, і змістовно, і проблемно. "Що нам Парменід? Що ми Парменіду?" [15, с. 161]. Звісно, ця віддаленість $\epsilon$ необхідною дистанцією для того, щоб охопити предмет цілісно, побачити граничні контури античної філософії, тоді як, наближаючись до даного предмета, ми краще бачимо його якісне забарвлення, деталі та нюанси, при цьому втрачаючи відчуття контуру. Але наше бачення і розуміння філософії виходить з принципово іншого світовідчуття та світовідношення: науковий характер нашого світогляду спочатку формує теоретичний "фрейм", у рамках якого відбувається імплементація 
теоретичних результатів у практику існування - від експериментального застосування до життєво-практичних рішень, тоді як для давнього грека вибір життєвої позиції та повсякденної практики передує утворенню теоретичних систем. Цю відмінність блискуче демонструє П. Адо у своїй праці "Що таке антична філософія?", зазначаючи: "Теоретичний філософський дискурс народжується, таким чином, із первісно екзистенційного вибору і підштовхує до нього тією мірою, якою його логічна та переконлива сила, той вплив, який він може мати на співрозмовника, спонукають учителів та учнів жити у реальній відповідності до їх первинних виборів" [3, с. 10] (дослідження П. Адо демонструє типове для "континентальної" філософії спрямування уваги на відчуття загального, окреслюючого та організуючого контуру предмета). Втім, тут доцільно було б поставити питання про буттєве підгрунтя екзистенційного вибору, оскільки це і є якісною основою для питання про начала античної філософії.

Тим не менше, попри очевидну дистанцію і світоглядну різницю антична філософія все одно мислиться як дещо споріднене із сучасними філософськими практиками - навіть тоді, коли поза увагою залишається зазначене питання про онтологічні начала античної філософії. Характер цієї спорідненості мислиться по-різному, і тут варто розрізнити та узагальнити найбільш поширені способи представленості античної філософії у сучасності.

Розгортання та розвиток сучасних теорій та систем логіки, що мають місце як у зарубіжній (передусім американських та британських аналітичних проектах), так і вітчизняній філософії, поширення впливу аналітичної традиції на російський та український інтелектуальні простори неминуче реанімують прискіпливу увагу до логіки Аристотеля, що мислиться як своєрідний поворот: "...уточнення вихідних понять аналітичної філософії на основі сучасної символічної логіки повертає нас до задумів Аристотеля, забутих чи відгороджених від сучасних кількома тисячоліттями. Ефект перевідкриття забутих істин добре знайомий в історії науки, але логіка Аристотеля з часів її виникнення ніколи не бувала в тіні новітніх успіхів наукового пізнання, вона належить і античності, і Середнім вікам, і найновітнішим часам" [17, с. 6]. Цими словами М. Попович відкриває круглий стіл, присвячений 2400-річчю народження Аристотеля. Також ряд останніх статей, опублікованих у "Філософській думці", засвідчують доволі грунтовну працю з проблемами логіки та філософії саме з позицій аристотелізму. Так, В. Навроцький зазначає, що "Беручи до уваги особливості практичних міркувань, з’ясувавши роль поняття прийняття в аналізі таких міркувань і питання про застосовність діалектичних моделей для аналізу спростовних міркувань, доходимо висновку про переконливі ознаки практичного повороту в сучасній логіці, який повертає логічну спільноту саме до Аристотеля" [18, с. 32]. 
У рамках рецепції філософії Аристотеля у вітчизняній думці актуалізується проблема перекладу термінології останнього українською мовою, що пов'язане із деколи невирішуваними складностями: "Відтворення оvбı $\alpha$ транслітерацією ("усія" - за прецедентами "логос", "категорія", "агора" тощо) є найменш травматичним для перекладу і коментування Аристотелевих текстів українською мовою" [16, с. 49].

Крім встановлення теоретичного зв'язку істотних аспектів античної філософії із сучасними філософськими проблемами, у вітчизняній думці все ж присутні спроби цілісно охарактеризувати наскрізну спорідненість античної філософії з параметрами мислення і буття людини взагалі. Тут показовим $є$ висловлювання А. Баумейстера: "Чи цікавить людей сьогодні антична філософія? Для мене це те саме, що запитати: "Чи існує в людини запит бути людиною?"' [14, с. 7]. Також варто звернути увагу на працю А. Ахутіна "Свропа - форум світу", що у доволі стислому вигляді демонструє історичну взаємопов'язаність та цілісність європейської культури як історичної події, що не мислиться без філософії, яка починається саме в античному мисленні: "Не існує ніякого європейського "раціоналізму" взагалі, а існує філософія, що питає, що означає мислити, розуміти, знати: в чому істинність істинного, як розуміє "чистий розум", як можлива (як задумується) мисляча думка, що $є$ первиннішим, початковішим за іiі апріорну архітектоніку?" ${ }^{1}[12$, с. 6$]$. Тут вже чути відлуння того самого запитування, що $\epsilon$ метою цього дослідження: як мислити начало мислення? Де шукати онтологічну засаду початку європейської філософії?

Для цього дослідження важливим є хоча б часткове зазначення способу проблематизації античної філософії в американсько-аналітичній традиції. Тут також присутня зафіксована нами локальність та інструментальність, коли ретельно досліджуються окремі вчення, думки та парадигми мислення у їх співвідношенні з сучасністю або у їх автентичному існуванні в рамках історичної традиції, проте практично відсутня увага до питання про начала античної думки. Втім, це є характерною ознакою аналітичної філософії, що, за власним визначенням, уникає постановки та занурення всередину метафізичних питань: "Про що неможливо говорити, про те слід мовчати" [19, с. 160].

Тут показовими є праці Дж. Аннас, які поки що не мають перекладів слов'янськими мовами, в яких автор актуалізує окремі аспекти античної філософії у контексті їх не-представленості у традиційному антикознавстві або непроробленості з точки зору відповідності сучасним теоріям. Так, у своїй праці "Hellenistic philosophy of mind" вона зазначає: "Чому еліністична філософія розуму вважалась непроробленою? Основною причиною $є$ те, що більшість теорій [розуму - С.В.] $\epsilon$ фізикалістськими; має місце дотримування думки, що розум $\epsilon$ чимось фізичним. I донедавна основою інтерпретації вченими еліністичної філософії було розуміння останньої як такої, де домінуючою ідеєю був

\footnotetext{
${ }^{1}$ Усі цитати з іншомовних джерел наведено у перекладі автора статті.
} 30 ISSN 1727-9313. ВІСНИК КНТЕУ. 2019. № 1 
дуалізм. Виходячи 3 цього, ми спостерігаємо наукові практики, які принципово відкидають еліністичні теорії як неадекватні, оскільки вони лише вивчають матеріальні умови для розумової діяльності" [4, с. 2]. Отже, вивчення античної філософії у рамках традиції американської філософії неминуче стикається 3 практично нездоланною відмінністю вихідних позицій останньої з античністю; ні про яке історичне співвідношення тут не йдеться. Усвідомлення необхідності долати цю неспіввіднесеність - це феномен буквально останніх десятиліть.

У рамках цього феномену актуалізується питання про створення адекватного методологічного підходу до античної філософії. I тут теж спостерігається спроба дистанціюватись від "континентальної", класичної традиції інтерпретації античності як основи наскрізної історії філософії. У колективній монографії М. Канто-Спербер, Дж. Барнса, Л. Брісона, Ж. Брюнсвіга, Г. Властоса "Грецька філософія" зазначено: "Стиль нашої Грецької філософії - це переважно стиль аналізу та рефлексії. Він характеризується відмовою від парафразування концепцій авторів, що вивчаються, і одночасно прагненням описати корпус їх творів, проаналізувати проблеми, які вони обговорюють, та розібратись у їх аргументах. У кожній роботі ставиться задача показати, які питання тлумачив філософ, що вивчається, які способи аргументації та концептуальні засоби він використовував і що вони дають для загального розуміння філософської проблеми. Автори цієї праці не поділяють ідею про те, що існує єдина форма прогресу - від мислителів доплатонівського періоду до філософів християнської ери. Вони визнають важливість впливу кожного філософа на нащадків; разом з тим кожна концепція розглядається сама по собі, незалежно від удаваного глобального філософського прогресу" [9, с. 2].

Відмова від ідеї неперервності філософського розвитку породжує потребу у формуванні такої методології, яка б автоматично здолала усі контекстуальні бар'єри на шляху до автентичності античної думки, представивши іiі у безпосередньому світлі самодостатності та самоцінності. I саме тут фіксується фронтальне упущення фундаментального питання про граничні виміри античної філософії та про ії онтологічні начала.

Так, в українському виданні "Sententiae" 2013 р. авторським колективом (М. Вольф, П. Бутакова, І. Бєрєстова) опубліковано статтю, що пропонує проект аналітичної історії античної філософії. Зновутаки, в тексті присутня доволі серйозна критика "попередніх" способів тлумачення історії філософії як наскрізного, неперервного способу розгортання думки. Проект характеризується таким чином: "Щодо нашого підходу, то, по-перше, ми підходимо до аналізу тексту з претензією на об'єктивність і відсутність ангажованості, якщо ми не ставимо перед собою надзавдання вписати мислителя в будь-якої історичний процес або дати йому оцінку як "типовому представнику" певної традиції. По-друге, нас цікавить не метафізична картина світу, вчення про Бога або моральні принципи, описані в досліджуваному тексті, а застосовувані автором методи обгрунтування тверджень, 
способи побудови теоретичної моделі та глибина опрацювання аргументації. У зв'язку з цим наш проект має мало спільного зі зазначеними [історичними та телеологічними - C.B.] напрямами континентальної гуманітарної науки" [11, с. 100]. Тобто істотним у рамках такого підходу є не "що" філософської проблематики, а "як" ії здійснення. Безумовно, це принципово важлива складова філософії, оскільки вона надає можливість мисленню відслідковувати способи свого здійснення на рівні рефлексії, логіки, самопрозорості та самозвітності. В рамках здійснення аналізу вказаного "як" автори пропонують формалізувати аргументацію античних мислителів мовою сучасної логіки: "Філософський інструментарій та методи, розроблені аналітичними філософами XX ст., виявляються незамінними для вирішення поставлених нами завдань. Ця методологія включає і способи формалізації аргументів, і увагу до синтаксису, логічної семантики, та й просто певну підвищену вимогливість до ясності мови і доводів. Тобто, аналітичний історико-філософський підхід не зводиться лише до написання формул, це, швидше, якийсь стиль або амбіція, засновані на презумпції нашої здатності виявляти аргументацію, що міститься в давньому тексті, а також на презумпції умов раціональності автора цього тексту, навіть якщо сам текст присвячений релігійним проблемам" [11, с. 106].

Загалом такий підхід наближає нас до більш чіткого розуміння способів розгортання античної думки, але він ніяким чином не суперечить філософським традиціям, що поіменовані авторами "континентальними". У сучасній тенденції критики тих філософських позицій та парадигм, що тяжіють до зображення історії філософії як певного метанаративу, присутня абсолютно необгрунтована відмова визнати за такими позиціями право і можливість працювати із локальними ландшафтами на рівні ретельного виявлення їх унікальності та самоцінності. Критиці підлягають в основному спроби осмислити історію філософії з позицій діалектики - як правило, гегелівської або марксистської; у вітчизняній філософії спостерігається до того ж доволі сумна і цілковито нефілософська за характером риторика стосовно діалектики як тоталітарного методу імплементації комуністичної ідеології, характерного виключно тоталітарній епосі існування СРСР. У такій оптиці будь-які спроби занурення у базові, онтологічні параметри співвідношення мислення і буття в історико-філософському ракурсі мисляться як дещо тоталітарне і токсичне відносно локального автора/ідеї/тексту/системи. Натомість пропонується тоталітарність методологічного та наративного плюралізму як самоцілі філософського мислення - на нашу думку, це у перспективі призводить до тотального зникнення можливостей філософського діалогу (втім, ця теза потребує окремого розгортання).

Будь-яка спроба сформувати окреслений метод абсолютно позаконтекстуального, безпосереднього та беззасновкового входження у тканину певного історико-філософського ландшафту - приречена на поразку, оскільки будь-яка формалізація є формалізацією в рамках тої 
чи іншої традиції (контексту, точки зору, положення у світі та історії...). Рух до позаконтекстуальності та "чистоти" у експлікації форм мислення відбувається значно складніше, і звісно, в історії філософії спроби "винесення за дужки" історичних, психологічних, культурних, суспільних "попередників" думки займають важливе місце. Проте існує фундаментальний онтологічний контекст, що дані спроби "обнуляє", "форматує", оскільки йдеться про те, що позиція, з якої ми абстрагуємо та формалізуємо той чи інший контекст - це завжди позиція нашого буття-у-світі, позиція первинної, дорефлексивної, дотеоретичної "закинутості", "орієнтованості" у світі. Саме тому питання про вихід на певну трансцендентальну позицію відносно граничних контурів мислення як такого $\epsilon$ настільки "непідйомною" проблемою - ставлячи питання про граничні контури, ми не виходимо за їх межі, як би ми не намагалися мислення формалізувати. Відсутня дистанція, що б створила необхідну оптику нашого погляду на мислення.

Тому ця дистанція настільки важлива в історико-філософському дослідженні. Саме через неї питання онтологічних, засадничих начал нашого мислення отримує необхідну конкретність. Фактично, запитуючи про начала античної філософії (у смислі - "що прагнули відшукати античні мислителі, починаючи мислити саме мислення?"), ми запитуємо про начало мислення взагалі. Тут доречним буде твердження В. Бібіхіна: "...Думка <..> не може бути нічим іншим, як першою філософією. Це означає, що вона повинна вміти починати з начала..." [10, с.15]. Кожне наше філософування, незалежно від історичного часу та функціональної спрямованості - це пошук відправної точки входження у мислення, а тому воно завжди "вперше".

Таким чином, упущення 3 уваги питання про онтологічні начала античної філософії або ж надання формальної відповіді на це питання нагадує фіксоване М. Гайдеггером упущення питання про буття як таке. Констатуючи питання про буття як пусте і найбільш загальне поняття, ми нічого істотного не висловлюємо про буття - навпаки, радше, готуємо грунт для його подальшого забуття. Якщо не ставити питання про фундамент філософського мислення, філософія перетворюється в набір розумових практик - корисних і практично ефективних (методологія науки, соціальний устрій, етичні максими, логічна формалізація мови...), позбавлений внутрішньої єдності, який надає розумовій активності загальний телос. I в рамках такої втрати єдності ми стверджуємо, що всі зазначені практики перетворюються на механічні інструменти, обернені та відчужені форми думки, ніяк не пов'язані з тим, що викликало їх до життя - 3 реальною цілісністю людського буття в світі. Небезпека такого відчуження - тема для окремого тексту.

Звісно ж, твердження про те, що можливість та спосіб вибудовування зв'язку між началами античного філософського мислення і філософським мисленням взагалі заперечуються у сучасній філософії цілком та повністю, не відповідає дійсності і не є метою цього дослідження. Відчуття необхідності встановлення сутнісних, буттєвих зв'язків між 
різними історико-філософськими формаціями не полишає сучасну філософію, існуючи як інтонаційно-лейтмотивно, так і цілковито артикульовано. Неможливо оминути увагою фундаментальні спроби М. Гайдеггера прискіпливо вслухатись у висловлене античними мислителями (при цьому не впадаючи у крайнощі, притаманні сучасній філософії мови) й одночасно утримувати буттєвий контур, в якому це висловлене до нас звернене [1] - фактично, дані спроби є прекрасним підгрунтям як для зазначеної аналітичної методології, так і для віднайдення базового зв'язку історико-філософських наративів у деяке універсальне ціле, що становить конкретну предметність філософського мислення.

Не можна не згадати розвідки В. Петрушенка стосовно філософії Парменіда, Геракліта, Піфагора, Сократа, софістів та мілетців у його книзі "Йов або про людське самостояння" [15], де автор блискуче демонструє те, що заслуга античної філософії не лише у запровадженні нової тематики для роздумів, але в якісному зрушенні способів розгортання мислення на граничному рівні: "Філософія починалася з "початку", але що було початком філософської думки? Знову-таки, можливо, ніяка інша філософія, крім античної, не дає нам можливості побачити все це майже зримо" [15, с.119].

Також заслуговує на увагу та ретельний розгляд таке твердження А. Ахутіна: "Немає смислу зіставляти філософські поняття, ідеї, концепції, минаючи вирішальне: сам розум, в якому і яким ці поняття вміють розуміти. Філософії - не завершені системи понять, а джерела думки, уми, що все ще можуть мислити. Починаючи розмову про трансцендентальні ідеї, Кант згадує ідеї Платона, але ідеї-проблеми Канта мають сенс у "чистому розумі" Канта, а ідеї-види Платона в його nous'i. Щоб перейти від одних до інших, треба зробити складну роботу перетворення розуму, свого роду metanoia. Власне філософія це взяття у власність - під власну відповідальність - всього сущого, світу" [13]. Тут імпліцитно присутнє пряме обгрунтування заявленої у дослідженні необхідності звертання до онтологічних, буттєвих начал античної філософії: попри окремішність, цілковиту історичну контекстуальність та світоглядну приналежність різних історико-філософських наративів, завжди існує шлях, яким думки, проблеми, бачення, ідеї, системи прямують 3 одного наративу у інший. Відмова від оптики наскрізного бачення історії філософії як родової властивості сучасного і несучасного людства (історії філософії як метанаративу, "ландшафтним дизайнером" якого і має бути історико-філософська методологія, що не уникає універсалізуючих окреслень), i, як наслідок, формалізація та відчуження питання про онтологічні начала античної (і будь-якої) філософії цей шлях закривають.

Висновки. У сучасній філософії (як у вітчизняній, так і зарубіжній, зокрема - американській та аналітичній) відчутно помітне схиляння до дескриптивно-інструментального дослідження античної філософії, що містить ризик втрати можливості виявляти універсальні, параметричні характеристики та граничні контури мислення як родової можли- 
вості людства. Таке схиляння призводить до формалізації та відчуження питання про начала античної філософії, i, як наслідок, до формалізації та відчуження філософії загалом. Постановка питання про онтологічні начала античної філософії - це надзадача, яка ще має бути виконана. Ïї необхідність зумовлена тим, що це єдиний спосіб формування адекватної трансцендентальної дистанції, через яку мислення у своїх сутнісних вимірах та буттєвих характеристиках постає як конкретний предмет філософського аналізу.

\section{СПИСОК ВИКОРИСТАНИХ ДЖЕРЕЛ}

1. Хайдеггер М. Парменид; пер. с нем. СПб.: Владимир Даль, 2009. 383 с.

2. Лосев А.Ф. Дерзание духа. М.: Изд-во политической литературы, 1989. 366 с.

3. Адо П. Що таке антична філософія. Київ: Культурна Асоціація "Новий Акрополь", 2014. 428 с.

4. Annas, Julia E. (1992). Hellenistic Philosophy of Mind. Berkeley: University of California Press, 246 p.

5. Annas, Julia E. (2000). Ancient Philosophy: A Very Short Introduction. Oxford University Press, $127 \mathrm{p}$.

6. Burnyeat, M. (1980). Canthe Sceptic Livehis Scepticism? Doubtand Dogmatism.Ed. by M. Schofield, M. Burnyeat, J. Barnes. Oxford, p. 20-53.

7. Burnyeat, M. (1982). Idealism and Greek Philosophy: what Descartessaw and Berkeley missed. The Philosophical Review, 1. (Vol. 91). January, 3-40.

8. Frede, M. Stoic Epistemology. The Cambrige History of Hellenistic Philosophy. Ed. by K. Algra, J. Barnes, J. Mansfeld, M. Schofield. Cambridge, 1999. p. 295-322.

9. Греческая философия, Т. 1. Антология. М. Канто-Спербер, Дж. Барнс, Л. Бриссон, Ж. Брюнсвиг, Г.Властос; пер. с англ. М.: Греко-латинский кабинет Ю. А. Шичалина. 2006, 520 с.

10. Бибихин В. Собственность. Философия своего. СПб.: Наука, 2012. 536 с.

11. Вольф М., П. Бутаков П., Берестов И. Аналитическая история античной философии. Sententiae. 2013. № 1 (XXVIII). C.96-108.

12. Ахутин А. В. Европа - форум мира. Київ: Дух і літера, 2015.88 с.

13. Ахутин А. В. Философское существо европейской культуры. Памяти Владимира Бибихина. URL: http://bogoslov-club.org.ua/?p=5205.

14. Баумейстер А., Вестель Ю., Звонська Л. та ін. Стан і перспективи українського антикознавства. Філософська думка. 2012. № 1. C. 5-25. URL: http://journal.philosophy.ua/issue/2012-no51.

15. Петрушенко В.Л. Иов или о человеческом самостоянии. Львов, Новий світ-2000, 2008. 339 c.

16. Панич О. Аристотелева "усія": між субстанцією, сутністю і неперекладністю. Філософська думка. 2016. № 5. C. 33-49. URL: http://journal.philosophy.ua/ issue/2016-no5.

17. Ахутін А., Баумейстер А., Білий О. та ін. Аристотель і аристотелізм: 2400 років по тому. Філософська думка. 2016. № 5. C. 6-26. URL: http://journal.philosophy.ua/ issue/2016-no5. 
18. Навроцький В. "Топіка" Аристотеля і практичний поворот у сучасній логіці. Філософська думка. 2016. № 5. C. 27-32. URL: http://journal.philosophy.ua/ issue/2016-no5.

19. Витгенштейн Л. Логико-философский трактат. М.: АСТ, 2018. 160 с.

Стаття надійшла до редакиії 19.11.2018.

\section{Wozniak S. Ontological principles of ancient philosophy.}

Background. In contemporary methodological practices, the reading of ancient philosophy manifests the fundamental insufficiency of contextual and meaningful immersion in the essential dimensions of philosophical thought presented by the ancient tradition. This insufficiency consists of the following: the question of the ontological and semantic principles of ancient philosophy is to establish a number of favorable and / or necessary prerequisites and causes of different order. This leads to the alienation of appeal to the principles of philosophy, which is a prerequisite for the alienation of philosophy in general.

The aim of the article is to analyze the methodological possibilities of entering the question on the beginning of ancient philosophy.

Materials and methods. The article uses the publications of domestic and foreign authors on these problems. In the framework of the research the general methods of historical-philosophical, theoretical and textual analysis are applied.

Results. The search for the method of non-textual, direct, and non-contextual entry into the fabric of the historical-philosophical landscape is doomed to defeat, since any formalization is formalization within that or another tradition. The movement towards out-of-context and "purity" in the explication of forms of thinking is much more complicated, and in the history of philosophy, the attempts to "cast behind the brackets" of historical, psychological, cultural, and social "mediators" of thought occupy an important place. However, there is a fundamental ontological context that eliminates these attempts: the position from which we abstract and formalize this or that context is always the position of our being-in-the-world, the position of the primary, pre-reflexive, pre-theoretical, "inclination", "orientation" in the world. Therefore, the question of the way out on a certain transcendental position regarding the boundary circuits of thinking as such is such an "unbearable" problem - when we raise the question of boundary contours, we do not go beyond their limits, as if we were not trying to formalize thinking. There is no distance that would create the necessary optics of our look at thinking.

The refore, such a distance is so important in the historical and philosophical study. Because of it the question of ontological, fundamental principles of our thinking gets the necessary concreteness. Asking about the beginnings of ancient philosophy (in the meaning "what did the ancient thinkers seek to find, beginning to think thinking itself?"), we ask about the beginning of thinking in general.

Conclusion. In modern philosophy (both in the domestic and foreign, in particular, the American and analytical), there is a significant inclination towards the descriptive-instrumental study of ancient philosophy, which contains the risk of losing the ability to identify universal, parametric characteristics and boundary contours of thought as the generic possibility of mankind. This leads to the formalization and alienation of the question of the beginning of ancient philosophy, and, as a consequence, to the formalization and alienation of philosophy in general. The question of the ontological principles of ancient philosophy is an over-task that still needs to be done. Its necessity is due to the fact that this is the only way of forming an adequate transcendental distance, through which thinking in its essential dimensions and existential characteristics appears as a specific subject of philosophical analysis.

Keywords: ancient philosophy, metanarrative, ontological principles of thinking, formalization, instrumentalization. 


\section{REFERENCES}

1. Hajdegger, M. (2009). Parmenid [Parmenides]. (Trans). SPb.: Vladimir Dal'.

2. Losev, A.F. (1989). Derzanie duha [Daring spirit]. M.: Izd-vo polit. l-ry.

3. Ado, P. (2014). Shho take antychna filosofija [What is ancient philosophy]. Kyi'v: Kul'turna Asociacija "Novyj Akropol'".

4. Annas, Julia E. (1992). Hellenistic Philosophy of Mind. Berkeley: University of California Press.

5. Annas, Julia E. (2000). Ancient Philosophy: A Very Short Introduction. Oxford University Press.

6. Burnyeat, M. (1980). Canthe Sceptic Livehis Scepticism? Doubtand Dogmatism.Ed. by M. Schofield, M. Burnyeat, J. Barnes. Oxford.

7. Burnyeat, M. (1982). Idealism and Greek Philosophy: what Descartessaw and Berkeley missed. The Philosophical Review, 1. (Vol. 91). January, 3-40.

8. Frede, M. Stoic Epistemology. The Cambrige History of Hellenistic Philosophy. Ed. by K. Algra, J. Barnes, J. Mansfeld, M. Schofield. Cambridge, 1999.

9. Grecheskaja filosofija, T. 1. Antologija [Greek philosophy, T. 1. Anthology]. (2006). M. Kanto-Sperber, Dzh. Barns, L. Brisson, Zh. Brjunsvig, G.Vlastos. (Trans). Moscow: Greko-latinskij kabinet Ju. A. Shichalina.

10. Bibihin, V. (2012). Sobstvennost'. Filosofija svoego [Ownership. The philosophy of own]. SPb.: Nauka.

11. Vol'f, M., Butakov, P., \& Berestov, I. (2013). Analiticheskaja istorija antichnoj filosofii [Analytical history of ancient philosophy]. Sententiae - Sententiae, 1 (XXVIII), 96-108.

12. Ahutyn, A. V. (2015). Evropa - forum myra [Europe - World Forum]. Kyi’v: Duh i litera.

13. Ahutin, A. V. Filosofskoe sushhestvo evropejskoj kul'tury. Pamjati Vladimira Bibihina [Philosophical being of European culture. In memory of Vladimir Bibikhin]. Retrieved from http://bogoslov-club.org.ua/?p=5205.

14. Baumejster, A., Vestel', Ju., Zvons'ka, L. et. al. (2012). Stan i perspektyvy ukrai’ns'kogo antykoznavstva [The state and prospects of Ukrainian classical studies]. Filosofs'ka dumka Philosophical thought, 1, 5-25. Retrieved from http://journal.philosophy.ua/issue/2012-no51.

15. Petrushenko, V. L. (2008). Iov ili o chelovecheskom samostojanii [Job or about human self-existence]. L'vov, Novyj svit -2000.

16. Panych, O. (2016). Arystoteleva "usija": mizh substancijeju, sutnistju i neperekladnistju [Aristotle's "mission": between substance, essence and immutability]. Filosofs'ka dumka Philosophical thought, 5, 33-49. Retrieved from http://journal.philosophy.ua/issue/2016-no5.

17. Ahutin, A., Baumejster, A., Bilyj, O. et. al. (2016). Arystotel' i arystotelizm: 2400 rokiv po tomu [Aristotle and Aristotelianism: 2400 years later]. Filosofs'ka dumka - Philosophical thought, 6-26. Retrieved from http://journal.philosophy.ua/issue/2016-no5.

18. Navroc'kyj, V. (2016). "Topika" Arystotelja i praktychnyj povorot u suchasnij logici ["Topic" of Aristotle and a practical turn in modern logic]. Filosofs'ka dumka - Philosophical thought, 5, 27-32. Retrieved from http://journal.philosophy.ua/issue/2016-no5.

19. Vitgenshtejn, L. (2018). Logiko-filosofskij traktat [Logical and philosophical treatise]. Moscow: ACT. 